\title{
Kan relationel fagkoordinering styrke de studerendes præstationer?
}

Janne Skakon, ph.d., adjunkt i Arbejds- og organisationspsykologi, Institut for Psykologi, Københavns Universitet.

\section{Reviewet artikel}

Høj kvalitet og forskningsbaseret undervisning for at sikre studerendes engagement og proestation i den afsluttende eksamen er højt på universiteternes dagsorden. Formålet med dette interventionsstudie var at designe og teste en fagkoordineringsmodel, som aktivt integrerer de forskellige uddannelseselementer og dermed ideelt styrker muligheden for de studerendes dybdeloering og performance ved den afsluttende eksamen. Både kvalitative og kvantitative data indikerer positive virkninger af relationel koordinering i kursusplanlaegningen. De kvalitative data påpeger overordnet tilfredshed blandt undervisere og studerende med indsatsen omkring relationel fagkoordinering, og kvalitative udsagn fra eksaminatorer samt kvantitative data peger på, at de studerende klarer sig bedre i deres afsluttende eksamen sammenlignet med studerende fra tidligere år.

\section{Introduktion}

Forskningsbaseret undervisning og undervisningskvalitet står højt på universitetets dagsorden (Det Samfundsvidenskabelige Fakultet, 2012). Dette bl.a. for at understøtte studerendes engagement og præstation ved den afsluttende eksamen, og for at klæde fremtidige kandidater på til arbejdsmarkedet. For at styrke undervisningskvaliteten har der i en årrække været fokus på constructive alignment, primært defineret af Biggs \& Tang (2011). De definerer begrebet som klar sammenhæng mellem undervisningsstrategier, læringsmål og evalueringsmetoder i et uddannelsesprogram. Det er kritiseret, at Biggs \& Tang ikke krediterer de læringsteoretikere, som de bygger på, som fx Bruner, Dewey \& Piaget (Andersen, 2010), og derudover er det diskuteret, hvorvidt forfatterne beskriver almene fornuftige principper, som det er vanskeligt at være uenig i (Andersen \& Tofteskov, 2008). Ikke desto mindre refereres der til constructive alignment i udarbejdelse af undervisnings- og læringsaktiviteter samt evalueringsmetoder. Og ifølge Biggs \& Tang retter denne tilgang sig direkte mod og måler læringsudbytte på måder, der ikke typisk opnås ved en mere traditionel tilgang til undervisning (Biggs \& Tang, 2011). Der sigtes mod dybdelæring karakteriseret ved en grundlæggende problemforståelse og evnen til at arbejde konceptuelt snarere end med isoleret detailviden (Biggs \& Tang, 2011; Ramsden, 2003). Det skal nævnes, at constructive alignment bl.a. har været kritiseret for - i rigid form - at medføre generalisering og simplificering, og til ikke pr. automatik at medføre dybdelæring (Andersen, 2010). 
At etablere en tydelig rød tråd, som beskrevet i constructive alignment-modellen, kan imidlertid være en udfordring i større fag, hvor mange interessenter er involverede. Et større fag består ofte af flere elementer, der kan involvere både interne og eksterne forelæsere, undervisningsassistenter og eksterne eksaminatorer, som arbejder mere eller mindre uafhængigt af hinanden. For at håndtere denne udfordring, udpeges en fagkoordinator, der påtager sig det overordnede ansvar for faget. En fagkoordinator har til opgave at organisere en række faglige aktiviteter, herunder planlægning og styring af det samlede undervisningsforløb, der involverer øvrige undervisere - og her bliver relationel koordinering som begreb og greb relevant. Relationel koordinering, der betegner koordinering af arbejdsrelationer gennem eksplicitering af fælles mål, delt viden og gensidig respekt, er særlig relevant for arbejdsprocesser, der er præget af gensidig afhængighed mellem de fagprofessionelles udførelse af opgaveløsningen, en vis grad af uforudsigelighed og defineret som tidsbegrænset (Gittell, 2001). Kommunikation er et nøgleelement, som skal foregå tilpas hyppigt, med den rette timing, være forståelig, præcis og problemløsende (Gittell, 2009).

Constructive alignment kan således betragtes som den ultimative opgave for fagkoordinatoren, hvor relationel fag-koordinering kan tjene som metode, idet der er flere parter involverede i løsningen af en fælles opgave.

Nærværende projekt, der fandt sted i forårssemesteret 2013, inddrager erfaringer fra faget Arbejds- og Organisationspsykologi (BA), der er bygget op som en forelæsningsrække suppleret med holdundervisning og afsluttende med en skriftlig eksamen i form af en ugeopgave. Data blev indsamlet blandt de deltagende 210 psykologistuderendestuderende samt 18 undervisere og eksaminatorer. Oplevelser af fordele og ulemper ved relationel fagkoordinering blev undersøgt. Endvidere blev karakterer sammenholdt over en fireårig periode, og suppleret med eksaminatorudsagn om evt. ændring i kvaliteten af eksamensbesvarelserne. Dette med henblik på at vurdere, hvordan studerende klarede sig i fagets afsluttende eksamen i semesteret med særlig vægt på relationel fagkoordinering (2013). Dette blev sammenholdt med eksamensbesvarelser fra studerende fra hvert af de tre foregående år.

\subsection{Fagkoordinatorens rolle}

En fagkoordinator "har det faglige ansvar for at koordinere faget", en definition der efterlader muligheder for at udfylde rollen på forskellig vis. I forlængelse heraf skal det nævnes, at der til fagkoordinatoropgaven traditionelt set kun har været begrænset allokering af timer, hvilket i sagens natur er med til at definere, hvordan opgaven løftes. I nærværende projekt blev det i udpræget grad valgt at basere fagkoordinatorrollen på principperne om constructive alignment og relationel koordinering, hvorfor der blev lagt særlig vægt på at planlægge den fulde strøm af aktiviteter med 
tydelig sammenhængskraft og med styrkede relationer mellem aktørerne hvor muligt, herunder:

1) At forberede og planlægge forelæsningsrækken med 14 forelæsninger i overensstemmelse med fagbeskrivelsen, herunder nærmere aftale med interne og eksterne undervisere for at sikre sammenhæng og konsistens.

2) At fastlægge pensum i samarbejde med forelæserne, herunder med tekster fra en gennemgående grundbog samt relevante og aktuelle forskningsartikler.

3) At rekruttere en gruppe af instruktorer med ansvar for den til forelæsningsrækken relaterede case-baserede holdundervisning, og at introducere instruktorteamet for samarbejdsprincipper mv.

4) At invitere til og afholde opstartsmøde for alle undervisere inkl. instruktorgruppe, med fokus på relationel fagkoordinering, eksemplificeret ved præsentation af forelæsere og emner, mulige koblinger mellem forelæsninger, en fælles ramme for forelæsningerne, herunder placering af emnet i historisk kontekst, præsentation af nøglebegreber, afsluttende refleksionsspørgsmål (Hiim \& Hippe, 2007), samt præsentation af krav om en kort skriftlig introduktion af de respektive forelæsninger og læsevejledning til pensumtekster, da der er fundet forskningsmæssig evidens for, at dette fremmer studerendes læring (Rienecker \& Troelsen, 2012).

5) At støtte instruktorerne i at lykkes med deres undervisningsopgave, fx via løbende supervision og facilitering af reflekterende processer ift. både proces og indhold (Andersen, 2005; Elbeshausen et al., 2013).

6) At kontakte forelæsere, herunder give feedback på deres præsentation forud for forelæsning tilstedeværelse under forelæsningen samt efterfølgende at videreformidle studerendes feedback (Gitell, 2010).

7) At forberede og udarbejde eksamensopgaver baseret på aktuelle cases som afrunding på faget (Ramsden, 2003; Smith, 2008).

8) At besøge de studerende i forbindelse med holdundervisning med særlig vægt på afklaring og forberedelse til eksamen (Smith, 2008).

9) At evaluere og bedømme de studerendes eksamensbesvarelser i samarbejde med eksterne eksaminatorer (Smith, 2008).

10) Endelig at evaluere det samlede fag, med input fra studerende, instruktorer, forelæsere og eksaminatorer med henblik på at kunne indvinde og udnytte læring og erfaringer konstruktivt og fremadrettet (Smith, 2008).

Semesterets undervisning i Arbejds- og Organisationspsykologi omfattede samlet set 210 studerende, 10 forelæsere (hvoraf halvdelen var eksterne), 7 instruktorer og 3 eksaminatorer. Den enkelte forelæser forestod en eller to forelæsninger relateret til 
hans eller hendes specifikke vidensområde, og som sådan var der en risiko for, at forelæseren ikke af sig selv var opmærksom på den bredere didaktisk kontekst, som han eller hun faktisk var en del af. I princippet kunne instruktorerne også forberede deres undervisning og arbejde selvstændigt, idet hver enkelt formelt set var allokeret til og ansvarlig for kun ét hold. Samtidig er der i studieordningen (og eksamensbestemmelserne) formuleret krav om, at den studerende bl.a. skal "anvende arbejdsog organisationspsykologisk teori analyserende over for arbejds- og organisationspsykologiske problemstillinger, og forholde sig analytisk til interventionsforslag" (Bachelor Program i Psykologi 2011-studieordningen). Ikke desto mindre giver et fag, såfremt der ikke er udpræget fokus på fagkoordinering, set fra de studerendes perspektiv, en betydelig risiko for en fragmenteret oplevelse af faget, som kan begrænse engagement og mulighed for dybdelæring og resultere i en relativt lavere bedømmelse af eksamensbesvarelser.

\section{Metoder}

Projektet blev gennemført som en intervention (Rothman, 1994), hvor en styrkelse af constructive alignment-elementet gennem relationel fagkoordinering havde til formål at øge performance ved eksamen blandt studerende. Dette skulle ske ved at designe og teste en fagkoordineringsmodel, som integrerede de forskellige uddannelseselementer for derved ideelt set at styrke muligheden for dybdelæring hos de studerende (Ramsden, 2003). Modellen var baseret på Biggs \& Tangs teori om constructive alignment (2011) og endvidere inspireret af principperne for relationel koordinering (Gittell, 2001).

\subsection{Dataindsamling}

Undersøgelsen er primært baseret på kvalitative data i form af udsagn fra følgende fire informantgrupper: studerende, instruktorer, forelæsere og eksaminatorer. Dataindsamlingen blev gennemført kontinuerligt over semesteret, dels gennem specifik feedback på det indledende møde, indledende og opfølgende samtaler med forelæserne, supervisionsmøder med instruktorer, møder med de studerende ved holdundervisning samt via e-mail-korrespondance, telefonsamtaler og personlig dialog i forbindelse med forelæsningerne. Yderligere blev relevante kvantitative og kvalitative data fra Institut for Psykologis evaluering af faget inddraget. Til brug for den kvantitative analyse af karakterudviklingen blev lister over afgivne karakterer over en fireårig periode indhentet, og disse resultater blev suppleret med udsagn fra eksaminatorer.

\subsection{Databegrcensninger}

Data er begrænset til at omfatte de personer, der viste synligt engagement i forhold til koordineringsaktiviteterne. Således mangler der data fra forelæsere og instruktorer, der ikke deltog i møderne eller ikke reagerede på e-mails. Ligeledes omfatter de 
studerendes udsagn udelukkende de, der tog kontakt via e-mail eller via deres instruktor, eller som indgik i dialog under fagkoordinatorbesøg på holdene. Kvalitative data repræsenterer derfor umiddelbart kun de aktivt engagerede grupper, og resultaterne skal tages med dette forbehold.

\subsection{Dataanalyse}

En mixed-method-tilgang (Creswell \& Clark, 2011) danner grundlag for undersøgelsen, der består af en kvalitativ dataanalyse af indsamlet feedback fra interessenter (studerende, forelæsere, instruktorer og eksaminatorer) og af en kvantitativ dataanalyse i form af simpel sammenligning af gennemsnitlige karakterer i faget over en fire-årig periode.

\section{Resultater}

I det følgende afsnit er uddrag fra informanternes udsagn grupperet i forhold til fordele og ulemper af relationel fagkoordinering. Slutteligt undersøges den potentielle effekt på de studerendes præstationer ved eksamen baseret på eksaminatorudsagn samt på relativt karakterniveau.

\section{1. Oplevede fordele ved relationel fagkoordinering}

Eksplicit feedback fra forelæsere og instruktorer peger på et højt engagement i undervisningen, der til dels kan forklares ved constructive alignment og aspekter af relationel koordinering. Fx giver fælles mål oplevelse af sammenhæng og understøtter udvikling af engagement. Følgende udsagn er fra forelæsere og instruktorer, der havde erfaring med faget fra før, den relationelle fagkoordinering blev iværksat. De gav udtryk dels for værdsættelse af initiativet og dels for, at den relationelle fagkoordinering bidrog til at eksplicitere den sammenhæng, hvori de indgik:

"Opstartsmødet var en god mulighed for at forstå den sammenhaeng, som vi deltog i" (Forelæser).

"Dine bestrabelser på at koordinere foreloesningsraekken har helt sikkert voret en fordel" (Forelceser).

"Det har voeret en fornøjelse at deltage i foreloesningsraekken" (Forelæser).

"[...] jeg oplevede, at det var vigtigt at signalere sammenhaeng og overblik" (Forelæser).

Også studerende bemærkede sammenhængen i faget:

"Det har voeret hjoelpsomt med en entydig defineret ramme og proces" (Studerende).

"Det er løbende blevet tydeligere" (Studerende). 
På holdene blev der arbejdet med cases som koblede direkte an til forelæsningerne og afspejlede eksamenskravene:

"De studerende var engagerede og glade for at arbejde med cases og deltog aktivt i diskussioner" (Instruktor).

Tidligere studier inden for relationel koordinering viser, at effektiviteten øges, kvaliteten forbedres og arbejdsglæden stiger, når medarbejdere lærer at respektere hinandens faglighed og opgaver og arbejder sammen mod et fælles mål (Gittell, 2009; Gittell, Seidner \& Wimbush, 2010). I nærværende projekt understregede instruktorerne kontinuerligt det lærings- og udviklingsmæssige udbytte af at deltage i teamsupervisionen og påpegede, at det styrkede deres egen relationelle fagkoordinering, deres undervisningskompetencer og deres evne til at reflektere over temaer, der udsprang af instruktorrollen. Og så peger de på fagkoordinatorens rolle i den proces:

"[...] sikrede udvikling og støtte gennem relevant og brugbar supervision" (Instruktor).

"(Koordinatorens) tilstedevarelse med faglig sparring ved opstartsmødet og de følgende supervisionsmøder [...] viste åbenhed over for nye måder og idéer og gav faglig støtte når det var nødvendigt" (Instruktor).

"[...] Jeg har voeret rigtig glad for at undervise holdet. Iscer instruktorteamet fungerede godt - du har virkelig støttet og bakket os op - det har varet fantastisk" (Instruktor).

Et andet væsentligt aspekt af relationel koordinering omhandler vidensdeling. Dette blev også bemærket som et positivt element:

"Opstartsmødet var en god mulighed for [...]at skabe eksplicitte links til andre foreloesninger og pensum" (Forelæser).

"[...] Meget positivt med koordinering mellem undervisere, og mulighed for at deltage ved hinandens forelcesninger og udveksling af prosentationer" (Forelæser).

Kommunikation er et nøgleelement i relationel koordinering, der skal foregå tilpas hyppigt og med den rette timing (Gittell, 2009). Det blev tilstræbt at kommunikere løbende både skriftligt og mundtligt, til gruppen såvel som til den enkelte. Et eksempel på, at det tilstræbte blev positivt modtaget, formuleres af en forelæser således:

"Det var virkelig dejligt, at du ringede ugen før jeg skulle undervise" (Foreloeser.) 


\subsection{Oplevede ulemper ved relationel fagkoordinering}

Både i underviser- og fagkoordinatorrollen opleves ulemper, primært i relation til arbejdsbelastning, og mismatch mellem investeret tid og aflønning. Som tidligere nævnt var det ikke alle forelæsere, der deltog lige aktivt i de fælles aktiviteter. At finde tiden synes at være en væsentlig udfordring:

"Jeg kan sandsynligvis ikke finde tid til at deltage i et formøde hvert år, men jeg synes, at idéen er god" (Forelæser).

Da motivationen for at bidrage som ekstern lektor sandsynligvis ikke er økonomisk begrundet, kan et udvidet engagement ud over det nuværende to-timers indledende møde naturligvis komme i konflikt med andre højere prioriterede opgaver. Derfor vil det være en væsentlig udfordring at engagere og fastholde forelæsere, der udover deres betydelige faglige bidrag ved forelæsningen, vil prioritere at indgå i en faglig ramme, hvor det koordinerende element er integreret, og som derfor er relativt mere tidsmæssigt krævende.

Gittell (2009) påpeger, at det er hensigtsmæssigt at inddrage de medarbejdere, der er villige til at engagere sig i teamwork, fra begyndelsen. Baseret på erfaringer fra dette projekt, der viste varierende grader af deltagelse blandt underviserne, kunne en mulig løsning være udelukkende at engagere forelæsere og instruktorer, der udtrykker interesse for og er villige til at deltage i de koordinerende aktiviteter og arbejde efter de aftalte retningslinjer for samarbejde. En udfordring i forlængelse af denne tilgang kan imidlertid være at sikre indholdsniveauet i undervisningen, dvs. at det faglige spektrum dækkes med de bedste ressourcer.

Set fra den fagansvarliges perspektiv har det udprægede fokus på relationel fagkoordinering utvivlsomt været tidskrævende i en grad, der ikke var afspejlet i de begrænsede timer, der formelt var afsat til opgaven. Prioritering og ressourcer er sidenhen revideret, og flere timer er blevet allokeret til fagkoordinatorrollen, så der nu er større overensstemmelse mellem formelle og reelle timer. Således er opgaven formelt blevet synliggjort, hvilket må anses som væsentligt for at sikre fokus og motivation.

\subsection{De studerendes eksamensproestationer}

Informanternes beskrivelser af deres erfaringer peger på, at det udvidede fokus på constructive alignment og relationel koordinering i undervisningsforløbet har påvirket de studerendes læring positivt, hvilket understøtter lignende pointer fra litteraturen (Biggs, 2011; Gitell, 2001). Instruktorer og flere studerende rapporterede bl.a., at mødet med den fagansvarlige i forbindelse med holdundervisningen var vigtigt, da det understøttede et relevant fokus på den forestående eksamen. En studerende nævner: 
"Det var voerdifuldt og beroligende med hensyn til eksamen, at du besøgte holdet" (Studerende).

Efter endt eksamen rapporterede eksaminatorerne, at eksamensopgaverne afspejlede et højere taksonomisk niveau sammenlignet med tidligere år. En sammenligning af de gennemsnitlige karakterer fra de forudgående fire år viser en positiv forskel på mellem 0,8 og 1,3 (fra 7,5 i 2010; 7,7 i 2011; 8,0 i 2012 hhv. 8,8 i 2013) på 12 trins-skalaen, dvs. en bevægelse i positiv retning. Det skal dog i denne forbindelse nævnes, at det på det foreliggende datagrundlag ikke kan konkluderes, at den positive tendens skyldes indsatsen omkring relationel fagkoordinering, både fordi der ikke er tale om den samme studenterpopulation og dermed ikke nødvendigvis en studenterpopulation med de samme forudsætninger, og fordi resultaterne af den simple sammenligning af karaktergennemsnit ikke kan betegnes som værende statistisk signifikante. Derudover fremgår det, at karaktérniveauet også er stigende, om end i mindre grad i årene før det udprægede fokus på relationel fagkoordinering. Ikke desto mindre kan eksaminatorernes udsagn om et samlet set højere niveau sammenholdt med de studerendes positive udsagn understøtte en hypotese om en gavnlig effekt af et øget fokus på fagkoordinering inspireret af principper for relationel koordinering og constructive alignment.

\section{Begrænsninger}

I forlængelse af de overvejende positive udsagn om effekten af relationel fagkoordinering bør det nævnes, at der var flere eksempler på adfærd blandt underviserne, der kunne opfattes som begrænset engagement i forhold til at bidrage til den nye ramme for faget. Nogle deltog ikke i det første møde og nogle var langsomme til at reagere på e-mails og til at fremsende deres undervisningsbeskrivelser, læsevejledninger mv. Det er en hypotese, at yderligere data fra denne gruppe sandsynligvis kunne bidrage til i højere grad at undersøge udfordringer ved den relationelle fagkoordineringsmodel, hvorved den samlede vurdering potentielt ville påpege flere kritiske vinkler, end det her er tilfældet.

En anden begrænsning omhandler metode, validitet og generalisérbarhed. I nærværende projekt udgør kvalitative data den primære datakilde. I et fremtidigt studie kunne man forestille sig et mixed methods-design, der i højere grad baseres på spørgeskemadata. Fx kan constructive alignment-aktiviteter og studerendes læring (overflade- og dybdelæring) undersøges med validerede værktøjer såsom SPQ (Biggs, 1987), R-SPQ-2F (Biggs, Kember \& Leungog, 2001) og CEQ (Ramsden, 1991). Relationel koordinering kan måles med The Relational Coordination Survey (oversat til dansk af Lundstrøm, 2014), om end det er påpeget, at det er vanskeligt at måle konkret på effekten af relationel koordinering (Edwards \& Lundstrøm, 2014) på trods af positive kvalitative udsagn. 


\section{Konklusion}

Både kvalitative og kvantitative data peger på positive effekter af relationel fagkoordinering. Kvalitative data indikerer overordnet tilfredshed med indsatsen blandt undervisere og studerende, og en kombination af kvalitative og kvantitative data viser, at de studerende, der deltog i forløbet med vægt på relationel fagkoordinering, klarede sig bedre i deres afsluttende eksamen i forhold til de studerende fra tidligere år. Der peges imidlertid også på udfordringer, hvad angår øget tidsforbrug - i særlig grad for fagkoordinator, men også for de øvrige involverede - hvilket kan ses som en begrænsende faktor $\mathrm{i}$ forhold til at implementere modellen.

\section{Perspektivering}

I nærværende projekt er der høstet konkrete erfaringer med en struktureret og målrettet, relationel fagkoordineringsmodel i forhold til et enkelt fag på en uddannelse. Der kan også være potentiale i at styrke sammenhængskraften mellem forskellige fag på en uddannelse ved at anvende relationel koordinering som værktøj til at fremme alignment på tværs af fag. Med fokus på såvel fælles mål for uddannelsen som på videndeling kunne frugtbare akademiske, undervisningsrelaterede og didaktiske drøftelser mellem fagansvarlige og øvrige undervisere komme både undervisere og studerende til gode og potentielt bidrage til yderligere udvikling af en uddannelse som et hele.

Janne Skakon er ph.d. og adjunkt inden for Arbejds- og Organisationspsykologi ved Institut for Psykologi, Københavns Universitet. Her forsker og underviser hun med saerligt fokus på ledelse, arbejdsmiljø, laering, forandringsprocesser, innovation og nye samarbejdskonstellationer. Hun har fungeret som fagkoordinator i faget Arbejds- og Organisationspsykologi, har undervist tvoerdisciplincert bl.a. i samarbejde med Institut for Statskundskab og underviser i praktikanalyse, et fag hvor de studerendes praksiserfaringer kobler an til teori for således at understøtte dybdeloering. Hun har desuden en baggrund inden for organisationspsykologi med 15 års erfaring som konsulent.

\section{Litteratur}

Andersen, H. L. (2010). Constructive Alignment og risikoen for en forsimplende universitetspædagogik. Dansk Universitetspaedagogisk Tidsskrift, 5(9), 30-35.

Andersen, H. L. \& Tofteskov, J. (2008). Eksamen og eksamensformer - betydning og bedømmelse. Frederiksberg: Samfundslitteratur.

Andersen, T. (2005). Reflekterende processer - samtaler og samtaler om samtalerne. København: Dansk Psykologisk Forlag.

Biggs, J. \& Tang C. (2011). Teaching for Quality Learning at University. Maidenhead: McGraw-Hill and Open University Press.

Biggs, J. B., Kember, D. \& Leung, D. Y. P. (2001). The revised two factor study process questionnaire: R-SPQ-2F. British Journal of Educational Psychology. 71, 133-149. 
Biggs, J. B. (1987). Study Process Questionnaire Manual. Student Approaches to Learning and Studying. Australian Council for Educational Research Ltd.

Creswell, J. W. \& Plano Clark, V. L. (2011). Designing and Conducting Mixed Methods Research (2nd ed.). Thousand Oaks, CA: Sage.

Edwards, K. \& Lundstrøm, S. L. (2014). Relationel koordinering - kan ændringer i samarbejde og relationer måles? Tidsskrift for Arbejdsliv, 16(4), 50-67.

Elbeshausen, H., Jensen, A. L. \& Riis, R. (2013). Fra kollegial supervision til fællesfaglig udvikling - et eksperiment med entreprenørskabsundervisning i faget kulturformidling. Dansk Universitetspaedagogisk Tidsskrift, 8(14).

Gitell, J. H. (2001). Supervisory span, relational coordination and flight departure performance: A reassessment of postbureaucracy theory. Organization Science, 12(4), 468-483.

Gittell, J. H. (2009). High Performance Healthcare: Using the Power of Relationships to Achieve Quality, Efficiency and Resilience. New York: McGraw-Hill.

Gittell, J. H., Seidner, R. \& Wimbush, J. (2010). A relational model of how highperformance work systems work. Organization Science, 21(2), 490-506.

Godwyn, M. \& Gittell, J. H. (2011). Sociology of Organizations: Structures and Relationships. Thousand Oaks: SAGE Publications.

Hiim, H \& Hippe, E. (2007). Laering gennem oplevelse, forståelse og handling. København: Gyldendal..

Lundstrøm, S. L. (2014). Relational Coordination in Danish General Practice. DTU Management Engineering, Technical University of Denmark.

Ramsden, P. (2003). Learning to Teach in Higher Education. London: Routledge.

Ramsden, P. (1991). A performance indicator of teaching quality in higher education: the Course Experience Questionnaire. Studies in Higher Education, 16(2), 129150.

Rienecker, L. \& Troelsen, R. (red.) (2013). 17 ting du kan gøre ved din undervisning. Konferencepublikation, Dansk Universitetspædagogisk Netværk.

Rothman, J. \& Thomas, E. (red.). (1994). Intervention Research: Design and Development for Human Services. Binghamton, NY: Haworth Press.

Smith, C. D. (2008). Design-focused evaluation. Assessment \& Evaluation in Higher Education, 33(6), 631-645.

\section{$\underline{\text { Internet }}$}

Institut for Psykologi, Det Samfundsvidenskabelige Fakultet (2013). Downloaded d. 12 februar, 2014 fra

http://www.psy.ku.dk/uddannelser/Bachelorstudiet/studieordning/Curriculum_ BA-2011_rev_2013.pdf

Det Samfundsvidenskabelige Fakultet (2012). Downloaded d. 12 februar, 2014 fra http://samf.ku.dk/fakultetet/strategi/ \& http://samf.ku.dk/erhvervskontakt/aftagerpaneler/ 
Akkrediteringsrådet (2013). Downloaded d. 12 februar, 2014 fra http://akkrediteringsraadet.dk/

Dansk Psykologforening (2014). Downloaded d. 12 februar, 2014 fra http://psykologkampagnen.dk/om-psykologkampagnen/ 